\title{
Coaching Strategy-based for Raw Sweet Potato's Small Medium Enterprise to be Leading in Payakumbuh
}

\author{
Hadi Irfani*, Rina Mariana, Fitri Yeni, and Sitti Rizki Mulyani \\ Universitas Putra Indonesia "YPTK" \\ Padang, Sumatera Barat, Indonesia \\ *hadi_irfani@gmail.com
}

Received 02 February 2016; Revised 13 March 2016; Accepted 21 June 2016

\begin{abstract}
The purpose of this study is to observe, interviews and collecting questionnaires regarding the provision of Small Medium Enterprise(SME) development strategy which can be made from Raw sweet potatoes SMEs in Payakumbuh.The method used in this study is a qualitative research method with a descriptive design, in which the data obtained in the form of words written or spoken of the people and observed behavior. The amount of sample 24 entrepreneurs, where sampling using purposive sampling technique. The research result is analyzed using SWOT analysis. The results showed that raw sweet potato entrepreneurs for SMEs in Payakumbuh city which is built on the service industry employers and trade provincial, district or city, able to be a driving force in the economic growth and development of the Payakumbuhcity. Judging from the characteristics of entrepreneurs based i.e.(1) Competence and commitment employers showed that employers have been trying to realize SMEs and superior quality, but has not been able to expand its business for the better because it is constrained by the lack of competence of the entrepreneurs themselves;(2) The aspects of coaching is based on the performance of the builder and the expectations of employers showed that employers expect to develop SME. Being an excellent business, but is not supported by the builder for a better performance in improving SMEs in all aspects.
\end{abstract}

Keywords: Strategy development; SME;potatoes;Employers.

\section{Introduction}

Payakumbuh city in West Sumatera Indonesia has potential in the sector of Small and Medium Enterprises (SMEs), according to statistics in Payakumbuh city there are 815 SMEs spread throughout the city region, and has absorbed 3,726 workers (www.payakumbuh.go.id ). Since the economic crisis that began in 1997, they still have an impact on the Indonesian economy until now. On the other hand the challenges of globalization AFTA (Asean Free Trade Area) in 2003 and plans for regional autonomy is getting closer, so that handling becomes very crucial and demanding governments Indonesia as a developing country to develop and optimally utilize the potential of its resources, especially the provinces in Indonesia, which has the potential of adequate resources and in this case,no exception in general to Payakumbuh city, West Sumatera. Potential SME in Payakumbuh is very important role in today's society economic activities of the large industry. Especially when associated with his role during the crisis, which serves as a buffer against economic resilience of society and even functions as well as social security, because it is through the presence of SMEs, this is a lot of expectation imposed especially in matters of economic activities, especially as a source of income [1].

In order to develop the potential of SMEs in the future, the government has formulated policies and programs, among others: develop industries producing raw materials / auxiliary / capital goods and industrial components, Improving inter-sectoral linkages with partnership. Industrial enterprises, increase in mastering of technology,enhance cooperation with the government apparatus businesses/business associations [1]. 
Increase utilization by implementing the priority scale of production capacity, the promotion and development of SMEs through partnership model and the development of commodities, strengthening SMEs through the promotion and development of integrated services, enhancement of integrated development and the development of SMEs. Support and facilities improvement, strengthening the role of public / private institutions / professionals to take an active role in the formation and development of SMEs [6]. The core of government policies and programs are forming a network of production, tissue builder, and networking market [8]. Selection of SMEs that cultivate the basic ingredients of cassava that there are myriads of Payakumbuh as an object, because at the moment SMEs which process the basic material of cassava pretty much grown in the city Payakumbuh, as well as this area is widely available raw materials as well as the background area that basically have food Specific made from cassava. But so far not been widely seen significant development of these SMEs [9].

In fact the demand for their produce quite a lot, but the SMEs are still not able to meet the overall demand tersebut. Even though, SMEs still seem not to accommodate many demands, however SMEs are still in the same state as the initial time established, or even disappear (close). It requires the creation of SMEs which are able to demonstrate superior growth and contribute to society and Payakumbuh city itself.

The purpose of this study is to observe, interviews and collecting questionnaires regarding the provision of Small Medium Enterprise (SME) development strategy which can be made from raw sweet potato SMEs in Payakumbuh. The method used in this study is a qualitative research method with a descriptive design, in which the data obtained in the form of words written or spoken of the people and observed behavior.

The rest of this paper is organized as follow. Section 2 describes analysis on strategic marketing of small and medium enterprises. Section 3 describes proposed methodology. Section 4 presents results and following by discussion. Finally, the conclusion of this work is presented in Section 5.

\section{Strategic Marketing of Small and Medium Enterprises}

The existence of an organization (business and non-business) is always associated with internal resources and external environment. There are six actors organizations to one another influence that company / company (C_1), Customer / costomers 【(C)_2), competitor / competitors 【(C)_3), intermediaries / channels 『(C)_4), Supplier / 『centers (C】_5), the strength of the macro environment $\left.\llbracket(C) \_6\right)$. The capability of an organization $\llbracket\left(C \rrbracket_{-} 1\right)$ to survive and thrive ditentuan by the power factor in adapting internal environment (C_1 to C_6).The strength of the external environment is rapidly changing and full of uncertainty (turbulance) that affect the capability of the organization in maintaining its market position. The implication, is not easy for an organization to achieve superior performance (superior performance). Lack of ability of an organization mepertahankan existence in an environment more likely caused by the gap between the internal strength of the external threat.The above situation shows a rapid shift in market and competition complex. The structure of the market a number of products has shifted from a monopoly to a competitive market structure. In this case, shifting customer demands (costumers requirement diversity) is very dynamic and the threat of increased competitor strength [10].

On the other hand the level of flexibility and adaptability of the organization to respond relatively low. These conditions make it difficult for the organization to match the capabilities or internal strength to the market demands and competition. In the business organization, business cases in telecommunication and national banking industry is an example that illustrates the above conditions.Capabilities mismatch that occurs in non-business organizations and businesses dependent competency result in an organization that is concerned in offering superior customer value (superior costumers value). This superior customer value is a condition that a requirement to create a positional advantage. Thus, capability mismatch problems of low capacity concentrated source of business organizations and no-business in creating positional advantage. The complexity of the competition in a dynamic show customers and an increase in the strength of competitors demanding business organizations and non-business to revitalize its business strategy [4]. There are two strategies that can be selected orientation and used organization: first oriented resource 
(resource-based) and less attention to the market, both market-oriented (market-based) and less attention to the resource. Both of these strategies orentation each has advantages and disadvantages. By because it is in designing the strategy, management may consider the combination of the two orientation strategies (integrated-based) [7].

Although the strategy has been to combine orientation but still stout organizations still lack the ability to created position excellence. In this case, the problem is not with the orientation of the strategy but lies in the consistency of the process of formulating strategies, ranging from the analysis of circumstances to control performance. In the embodiment finally superior organizational performance is determined by the ingenuity of management in addressing the situation during the process of drafting the management and implementation of the strategy.In view of the Day [3] Strategies is direction statement that includes a number of dimensions, namely, palm, advantage, access and activities. The dimensions were interdependent and collectively determine strategy [13]. Company have to choose and define target markets to be served, establish something that differentiates the company with competitors, communicate and use the entire distribution to reach the target market, as well as determining and implementing scale and cover the right activity. Other dimensions are as important adaptation of a strategy to address the threat and take advantage of opportunities [3].

Flexibility and adaptability related business strategy with the effectiveness of these strategies in responding to market demands and the power of dynamic competition. In a strategic marketing perspective, the current strategy and that will come must focus on customers (costumers focus) and competition (competitor-centered) by improving the synergy of business operational function. The orientation of this kind of marketing strategy related to strategic vision in the management of superior performance [12].

With the development of strtejik proper vision, understand its dimensions and break them into every activity management capabilities are expected to achieve an ideal match to create superior customer value to achieve a positional advantage, so the superior organizational performance can be achieved. Model Strategy Market driven in activities to analyze the characteristics and strength of competition in the market is important to measure the attractiveness of the market and determine the competitive arena or target markets to be served [5,11]. Marketing strategic perspective puts customer value as the core dimensions in the creation of positional superiority and performance of an organization [15].The development of strategic marketing including:

a. Arena ( A1 ), Where to Compete ?

b. Advantage ( A2 ), When to Compete?

c. Access ( A3) How to Compete ?

d. Activities ( A4), Cross functional coordination .

e. Adapt ( A5 ), the foresight of the company / organization to adapt to changes in the environmental situation .

Therefore, SMEs belonging to the small business limit and Medium Enterprises (SMEs) according to law No. 9 of 1995 concerning SMEs, the definition of small industry is defined as follows:

"Small industry is the economic activity that is carried out by individuals or households maupan suau body which aims to produce goods or services for commercial trade who has a net worth of at most Rp. 200 Million and has annual sales value of Rp. 1 billion or less".

Restrictions on business scale according to BPS, which is based on the criteria of the number of workers, began to attempted within the Ministry, namely [14]:

a. Industry and Trade Micro (ID-Micro): 1-4 people

b. Trade Industries and Small (Small-ID): 5-19 people

c. Industry and Trade Medium (ID-Medium): 20-99 people

d. Industry and Trade of the (ID-Large): 100 persons and above

There are four groups of commodities to be priorities for this development by the Ministry of Agriculture, namely: 
a. Groups SMEs regional economic drivers including Tool Agricultural machinery (Agricultural Machinery); Jewelry; Motorization (Boat Fishermen); Snacks; Alam Sutera; Tannery; Palm Cooking Oil; Fertilizer; Salt; Traditional Weaving; Roof tile; Traditional Agricultural Equipment; Webbing; Other appropriate proposals and potential of the region.

b. SME Support Group including Components of Motor Vehicles; Machinery components; Electronic Components; Goods Rubber and Plastics.

c. Export Oriented SME Group including Processed fish; Crackers; Leather goods; Shoes / Footwear; Apparel; Textile goods; Essential oil; Charcoal wood / Shell; Wood furniture; Rattan forniture; Ceramics / Pottery; Jewelery; Embroidery embroidery; Children toys; Woodworking; Woven crafts; and Batik.

d. New Initiatives SME Group including computer coftware and bio technology.

The motor of the greatest role in the development of SME businesses are SMEs, whichshould be empowered so that entrepreneurs have the following capabilities:

a. Has the insight and entrepreneurial spirit that is resilient, patriotic (love the productoin the country), and professional.

b. Capable of identifying, developing, or take advantage of business opportunities.

c. Able to utilize productive resources and access to markets (local, domestic, and export).

d. Having a business management skills, expertise, and technical skills / technology.

e. Able to build competitiveness (sound efficient, productive, and quality, proactive - creative innovative).

f. Has a strong commitment to promoting SMEs has materialized in the form of attention, resource allocation / funding, effort and more time for the development of SMEs.

g. Having a conceptual insight to make SME development program that is efficient and effective

h. Be consistent in the spirit of integration to jointly support / implement SME development programs in accordance with the role, functions, and duties of each.

\section{Methodology}

Variables that are discussed in this research is the competence of the entrepreneur, committed entrepreneurs, who can explain the mainstay employer profiles, industry attractiveness, business strength that can explain the flagship SME business as well as data about the entrepreneur.

\subsection{Research design}

The method used in this study is a qualitative research method with a descriptive study design. While the unit of analysis in this study is Raw sweet potato'sSMEin the city Payakumbuh. Execution time is sectional.

\subsection{Data and Analysis}

The study population is 27 SMEs in Payakumbuh. While the sample in this study amounted to 24 SMEs that match the criteria. The sampling technique using non-probability sampling technique, in which a sample of community leaders and relevant agencies to be considered contained in the SME environment chosen for the sample [2].The data collection is using: (1)Questionnaire with two models, namely: a model questionnairewhich is for entrepreneurs (owners of SMEs) and the questionnaire models B, which isfor SMEs (SME business); (2)Direct and unstructuredinterview;

(3) The non-participant observation.Data analysis methods are described as follow:

a. Using a SWOT analysis on entrepreneurs and SMEs.

b. Data based on the level of interest and the level of SMEs crucial.

c. Data based Capability (Business Strength) and Industrial Attractiveness SMEs. 


\section{Results and Discussion}

\subsection{Overview of Raw sweet potato'sSME in Payakumbuh}

Payakumbuh have potential in the sector of Small and Medium Enterprises (SMEs), according to statistical data Payakumbuh, there are 815 SMEs engaged in different fields of production, and spread throughout the region and the town has absorbed 3,726 workers. In this study there were 32 pieces of SMEs that process basic materials Raw sweet potato.Most of the general revenue Payakumbuh community comes from the SME sector, probably because the area is relatively small, and limited natural resources. SME sector is the backbone of the economy of the city is also not yet fully able to count on to sustain the lives of people who live hang to wrestle this effort, because the existing SMEs can grow and disappear without community and stability in the process of growth and development.

\subsection{Characteristics of Raw sweet potatoSME Entrepreneurs in Payakumbuh}

In extracting the characteristics of SMEs in the city Payakumbuh, West Sumatera, Indonesia done by analyzing the competence of entrepreneurs and businessmen committed itself. based on research results obtained information the competence and commitment of employers is seen as an advantage that must be owned by a businessman as well as an opportunity that they should take advantage of as quickly as possible.Here are the information:

a. Entrepreneurs with high competence and commitment being, these entrepreneurs have attempted to create an SME and superior quality. However, lack of experience and training make these entrepreneurs are still not able to realize a superior SMEs.

b. Entrepreneurs with high competence but still lacking the commitment to try. The businessman was a bachelor who still hesitate to rely SME sector, entrepreneurs are still hoping to be a civil servant so that he has not been able to give great attention to SMEs lead. Employers are only continue what has been started by their parents respectively. Employers in this quadrant still need more encouragement so that they are sure to SMEs lead.

c. The entrepreneurs who could be categorized as a senior businessman. Experiences that enable them to survive as an entrepreneur, but they have not been able to give change, especially in terms of managerial.

d. A senior entrepreneurs are turning to SMEs based Raw sweet potato because their previous efforts are not able to survive in the competition. a businessman with moderate competence and commitment are lacking in terms of managing their business. So that entrepreneurs in this quadrant have not been able to compete with the market share.

e. This businessman is a businessman who has a strong commitment to developing its business. These entrepreneurs have utilized the best possible opportunity to improve their competence, with frequent follow any training provided by the government. However, limitations in terms of formal education inhibit the development of the business, because businesses in this quadrant have not been able to analyze the development and the demands of the market/consumer. Employers in this still need guidance, especially in terms of marketing strategy, because this kind of education still not been received.

f. A businessman who is quite aware of the limitations of human resources, and strive to explore the science. However, due to limitations of the coaching program, they are not able to improve their limitations to the science of marketing their businesses.

g. Employers in this quadrant is hard to be fostered or developed, as employers in this quadrant are not willing to develop competence and commitment in business.

\subsection{SME Development Characteristics Made From Potatoes in Payakumbuh}

\subsubsection{Characteristics Development Conducted by NGO}

Non Government Organization ( NGO ) is the most widely provide guidance on educational institutions and the coaching. Coaching is done by NGOs it is still lacking, but the expectations of employers towards fostering high enough. This is because it is still very lack of attention to the SME sector NGOs in the city Payakumbuh.In this analysis, all aspects of its development is 
expected by the employer is still inadequate. This means that the SMEs expect big enough for development of NGOs, but NGOs in the Payakumbuh city still not able to meet these expectations.

\subsubsection{Characteristics Development Conducted by Financial Institutions}

Coaching conducted by financial institutions, including banks more emphasis on the financial aspect, especially in financial management itself.In this guidance, there is a difference in perception between the banks to SMEs. The banks in addition to provide loans, they also focus on the financial management of the company itself, through an explanation of the financial separation between the family and the company. On the contrary, the companies expect too much for the banks to be able to always be assisted in terms of capital, without them trying to manage capital and utilize existing capital to better.In this analysis, the characteristics of the development financial institutions (banks) we can see in the following explanation:

a. In the second quadrant, we can see that fostered aspect is the financial aspect. In this case there is a difference between the expectations of the coaching by the trainer. Parties builder more focused guidance to financial management sector (working capital), being the employer actually expect from the builder in the form of working capital.

b. In the fourth quadrant, we can see that in the coaching aspect is the aspect of human resources. The banks to give serious attention to this human resources sector, with the hope that businessman will produce superior profile and is able to manage the financial (capital) better.

c. In the fifth quadrant, dug aspect is the aspect of production, marketing, research and development. But in this case, the builder has its limitations.

\subsubsection{Characteristics Development Conducted by the Department of Industry and Trade}

Coaching is done by the department of trade Peridustrian and more emphasized on aspects of production, research and development and marketing.

In this development, the Ministry has done a pretty good effort in the development of SMEs. Here's the explanation:

a. Related builder performance in aspects of the research and development look very good, according to what is expected by SMEs.

b. Builder performance in the aspects of production and marketing aspects are considered satisfactory by SMEs.

c. Expectations of employers in the financial aspect, especially in terms of capitalization, but the performance of the builder it is still sorely lacking.

d. Entrepreneur human resource development has been carried out with the maximum by the builder.

Based on observations in the previous section, we see how the characteristics of each raw material potato SMEs in the city Payakumbuh. we can see how the requirements affect the commitment and performance of each of these businesses. It can be seen how the requirements affect the commitment of each SMEs. Their need for employment is considered more feasible in accordance with the level of their education, making their commitment to SMEs that they lead to less. In this case, the level of higher education would make employers think that the job is suitable for those with higher education not just as a businessman, but as an employee, resulting in their commitment to lead the SMEs themselves to be reduced. In contrast to the highly educated entrepreneurs are relatively lower. They desperately need the support of SMEs as their life, and they think SMEs as the only employment is capable of being the foundation of their lives and family, this brings a high commitment in running the business.

The city Payakumbuh, where the NGO is still fairly small, and only a few are paying attention to the development of SMEs. Coaching by NGO is only a briefing to the legality of a business such as licensing and other.The SMEs still need a lot of guidance, especially for the 5 aspects that they expect, but there are also gaps expectation / expectations of employers with NGOs. Although NGOs are still not able to provide sufficient guidance, but from the side of entrepreneurs always expect helpin the capital, although they realize this is not the capacity of the NGO itself. 
The existence of banks as partners in the Payakumbuh city SMEs felt sufficiently large role. The banks have sought sufficient guidance in accordance with its capacity, but in this case there are still differences with the expectations of employers. The banks seek guidance in the financial sector with grooves that fit their understanding of SMEs themselves, the banks seek maturity of SMEs in terms of finance, particularly in financial management itself, but the SMEs it is always directing attention and help it towards capital assistance. Without them, it is hard to realize how their ability to manage finances itself. In the fifth aspect of the expected employers, industry and commerce department has sought the guidance of the maximum.

\section{Conclusion}

In this paper, coaching strategy-based raw sweet potato's small medium enterprise to be leading in Payakumbuh city, West Sumatera Indonesia has been discussed. Based on the results of research and data analysis, it can be concluded as follows:

a. Employers seed for small and medium enterprises in the Payakumbuh city well as an entrepreneur built from the department of industry and commerce at provincial and district / city to become the driving economic growth and development in the city Payakumbuh.

b. In mapping the characteristics of SMEs in the Payakumbuh city based on competence and commitment of employers, it can be seen that the level education entrepreneurs not guarantee the size of the commitment of the entrepreneurs themselves to run with more seriously. instead efforts the highly educated enterpreneurs still perceived that SMEs will not necessarily ensure its survival., thus weakening their commitment in the management and development of SMEs. Unlike the less educated employers, they actually have a high commitment because they assume only that they manage the SMEs which will become the foundation of their lives.

c. From the research, we concluded that the competence, commitment and performance of NGOs, banking and services industry and trade as an opportunity and power to be able to be utilized and well prepared by entrepreneurs SMEs to be able to expand its business towards the better.

d. In general, coaching is done by the builder still less able to meet the expectations of employers, especially the coaching is done by NGOs. Most SMEs expect expect guidance sustainable and directed that include: design, process development, financing, and marketing.

\section{Acknowledgement}

This work is supported by Universitas Putra Indonesia "YPTK"Padang, Sumatera Barat, Indonesia.

\section{References}

[1] Aaker, D.A. 2001. Strategic Market Management. Sixth Edition, John Willey \& Sons,Inc., New York.

[2] Arikunto, S. Research Procedure 1992. An Approach, Jakarta: Bina Script.

[3] Bergeron, Bryan. 2002. Essential of CRM: A Guide to Customer Relationship Management. John Wiley \& Sons, Inc., New York.

[4] Colley, J.L, Jacquiline L. D. and Robert D. 2001. Corporate Strategy. The McGraw-hill Executive MBA Series., New York.

[5] Cravens, D.W. and Nigel F. P. 2003. Strategic Marketing. McGraw-Hill., Boston.

[6] Gordon, I.H. 2002. Targeting Competitor: Winning the Battle for Market and Customer Share. John Wiley \& Sons., Canada.

[7] Gummesson, E. 1999. Total Relationship Marketing: Rethinking Marketing Management: From \$ Ps to 30Rs. Butterworth Heinemann, Oxford. 
[8] Haskett, James L, W. Earl Sasser, Jr., And Leonard A. Schlesinger. 1997. The Service Profit Chain: How Leading Companies Link Profit and Growth to Loyalty, Satisfaction, and Value. The Free Press., New York.

[9] Horovitz, Jacques. 2000. Seven Secrets of Service Strategy. Prentice-Hall, Harlow., England.

[10] Kotler, Philip and Karen F.A. Fox. 1995. Strategic Marketing for Educational Institution. Second Edition, Prentice Hall, Inc., New Jersey.

[11] Minett, Steave. 2002 B2B Marketing: A Radically Different Approach for Business to Business Marketers. Prentice-Hall., London

[12] Porter, Michael E. 1993. Competitive Strategy: Techniques for Analyzing Industrial and Competitors. The Free Press, A Division of Macmillan, Inc., New York.

[13] Schonberger, Richard J. 1990. Building Achain of Customers: Linking Business Functions to Create the World Class Company. The Free Press, A Division of Macmillan, Inc., New York.

[14] Sucherly. 1996 Marketing Strategies in Small and Medium Industries Commodity and Its PhD Effect on Marketing. Dissertation UNPAD., Bandung.

[15] Sucherly. 2002. Mapping of Small and Medium Industries Commodity seed and Entrepreneurs mainstay in the city of Sukabumi. P3B-Padjadjaran University, Bandung. 